\title{
First record of the freshwater copepod Mesocyclops paranaensis Dussart \& Frutos, 1986 (Copepoda: Cyclopoida: Cyclopidae) from Colombia
}

\section{Primer registro del copépodo de aguadulce Mesocyclops paranaensis Dussart\& Frutos, 1986 (Copepoda: Cyclopoida: Cyclopidae) de Colombia}

Juan M. Fuentes-Reinés * 1

https://orcid.org/0000-0001-5809-4271

juanfuentesreines@gmail.com

Eduardo Suárez-Morales ${ }^{2}$

https://orcid.org/0000-0003-2051-8707 esuarez@ecosur.mx

Pedro Eslava ${ }^{1}$

https://orcid.org/0000-0002-4779-1589 pemo2002@gmail.com

\section{*Corresponding author}

1 Universidad del Magdalena, Grupo de Investigación en Biodiversidad y Ecología Aplicada, A. A. 731. Santa Marta, Colombia.

2 El Colegio de la Frontera Sur, Unidad Chetumal, A.P. 424, 77014 Chetumal, Quintana Roo, México.

\section{Citación}

Fuentes-Reinés JM, Suárez-Morales E, Eslava P. 2021. First record of the freshwater copepod Mesocyclops paranaensis Dussart \& Frutos, 1986 (Copepoda: Cyclopoida: Cyclopidae) from Colombia. Revista peruana de biología 28(2): e20469 (Mayo 2021). doi: http:// dx.doi.org/10.15381/rpb.v28i2.20469

\section{Presentado: $\quad$ 25/01/2020}

Aceptado: $\quad 11 / 05 / 2021$

Publicado online: 25/05/2021

Editor:

Leonardo Romero
Abstract.

The Neotropical free-living freshwater cyclopoid copepod Mesocyclops paranaensis Dussart \& Frutos, 1986 was found in a small temporal pond in La Guajira, northern Colombia. Hitherto, it has been reported from Argentina, Paraguay, and Brazil. This is the first record of this species in Colombia, its northernmost finding in South Ameri$\mathrm{ca}$, and the fourth locality in which this species has been recorded from. Mesocyclops paranaensis can be distinguished from its closest congeners by a unique combination of the characters of the female, including: 1) leg 4 intercoxal sclerite with two large, acute projections; 2) P3, P4 intercoxal sclerite caudal surface lightly pilose; 3) seminal receptacle with narrow lateral arms and weakly convex anterior margin; 4) second antennary endopodite with seven setae, and insertion of antennary exopodal seta with adjacent spinules; 5)frontal surface of P1 basipodite ornamented with long spinules; 6) posterior margin of anal somite with continuous row of spinules; and 7) inner margin of caudal ramus hirsute. The Colombian population shows some subtle morphological differences with respect to previous reports.

\section{Resumen}

El copépodo ciclopoide de agua dulce Mesocyclops paranaensis Dussart \& Frutos, 1986 fue encontrado en un pequeño estanque temporal al norte de La Guajira. Hasta ahora, esta especie había sido registrada en Paraguay, Argentina y Brasil. Este es el primer registro de esta especie sudamericana en Colombia, su registro más septentrional en América del Sur, y la cuarta localidad en la que se registra. Mesocyclops paranaensis se puede distinguir de sus congéneres más cercanos por una combinación única de caracteres que incluyen: 1 ) esclerito intercoxal de la pata 4 con dos grandes proyecciones puntiagudas, 2) esclerito intercoxal de la pata 3 y pata 4 ligeramente piloso, 3) receptáculo seminal con brazos laterales estrechos y margen anterior débilmente convexo, 4)segundo segmento endopodal de la antena con siete setas, inserción de la seta exopodal de la antena con espínulas, 5) superficie frontal del basipodito de la pata 1 ornamentada con largas espínulas, 6) posterior margen del somita anal de la hembra con hileras continuas de espínulas y 7) margen interno de la rama caudal pilosa. Se proporciona una breve descripción de esta especie e ilustraciones de la población colombiana y se compara con su congénere más cercano. Los especímenes de Colombia muestran algunas diferencias morfológicas con respecto a los reportes previos acerca de esta especie.

Palabras clave:

Mesocyclops; Guajira; biodiversidad; zooplancton de agua dulce; estanque temporal; distribución; región Neotropical; nuevo registro.

Keywords:

Mesocyclops; Guajira; biodiversity; freshwater zooplankton; temporary pond; distribution; Neotropical region; new record. 


\section{Introduction}

The widespread freshwater cyclopoid copepod genus Mesocyclops Sars, 1914 can be found in a wide variety of freshwater habitats, including temporal and permanent pods, lakes, rivers, swamps (Hołyńska et al. 2003, Alekseev et al. 2013, Papa and Hołyńska 2013, FuentesReinés et al. 2013), and even coastal hiposaline ponds (Suárez-Morales et al. 1999). It is considered as a cosmopolitan group with greater affinity for tropical areas, especially in eutrophic water bodies (Luong et al. 2020). This genus is one of the most speciose in the subfamily Cyclopinae; with nearly 80 valid species known (Papa \& Hołyńska 2013, Tran \& Hołyńska 2015), only 21 have been reported from the Neotropical region (GutiérrezAguirre et al. 2006, Suárez-Morales et al. 2020). Of these, only six have been hitherto recorded from Colombia: Mesocyclops aspericornis (Daday, 1906), M. brasilianus Kiefer, 1933, M. longisetus (Thiébaud, 1912), M. meridianus (Kiefer, 1926), M. reidae Petkovski, 1986, and $M$. ellipticus Kiefer, 1936.

Mesocyclops paranaensis, originally reported as $M$. meridianus and $M$. ellipticus has been recorded from $\mathrm{Pa}-$ raguay and Brazil respectively (Lowndes 1934, Dussart \& Frutos, 1986, Gutiérrez-Aguirre et al. 2006). Mesocyclops paranaensis is restricted to the Neotropical region (Gutiérrez-Aguirre et al. 2006, Suárez-Morales et al. 2020).

The aim of this contribution is to document the first record of M. paranaensis for Colombia, which expands its known distributional range in South America, and also to provide comparative morphological data and illustrations of the Colombian specimens.

\section{Material and method}

Biological samples were obtained from a small temporary pond in the northern part of La Guajira-Colombia $\left(11^{\circ} 16^{\prime} 24.67^{\prime \prime N}, 73^{\circ} 07^{\prime} 22.92^{\prime \prime} \mathrm{W}\right)$. Qualitative surveys were performed during October and November 2018. Environmental parameters were measured with a WTW 3111 conductivity meter gear. Water samples were obtained using a bucket of $65 \mathrm{~L}$, filtered with a $55 \mu \mathrm{m}$ meshsize plankton net to obtain concentrates of $500 \mathrm{~mL}$ that were fixed and preserved in 96\% ethanol. In the laboratory, samples were stained with Bengal rose and concentrated to a volume of $50 \mathrm{~mL}$. A Bogorov chamber was used to sort and count copepods, with the aid of a stereomicroscope; copepods were taxonomically examined under a compound optical microscope in a drop of glycerol. Specimens were measured in ventral position, from the anterior end of the cephalothorax to the posterior margin of the caudal ramus and then dissected to examine the taxonomically relevant appendages, which were mounted in semi-permanent slides. The appendages with taxonomic relevance were photographed using a Kodak Easy Share C140 digital camera adapted to a compound microscope at $1000 \times$ magnification. Drawings of taxonomically relevant structures were prepared with the aid of a camera lucida mounted on an Olympus BX53 semi-motorized microscope with Differential Interference Contrast optics. The identification of this species followed the keys, illustrations, and descriptions by Dussart \& Frutos (1986), Gutiérrez-Aguirre et al. (2006), and Suárez-Morales et al. (2020). Our morphological remarks and complementary description followed Huys and Boxshall (1991). The following abbreviations are used in the text: P1-P6 = first to sixth legs; EXP = exopod; $\mathrm{ENP}=$ endopod.

Voucher specimens of M. paranaensis were deposited at the Centro de Colecciones Biológicas held at the Universidad del Magdalena, Colombia (CBUMAG:MEI:0827) where they are available for consultation and/ or further examination.

\section{Results}

ORDER CyClopoIdA BURMEISTER, 1835

FAMILY CyClopidAE RAFINESQUE, 1815

SUbFAMILy CyClopinaE RAFINESQUE, 1815

GenUS MeSOCYCLOPS SARS, 1914

Mesocyclops paranaensis Dussart \& Frutos, 1986, p. 312 , fig. $46-50$

Mesocyclops meridianus in Lowndes (1934: p. 80, 107)

Material examined: 7 adult female specimens collected by one of us (JMF-R) from an ephemeral pond located in La Guajira, northern Colombia $\left(11^{\circ} 24^{\prime} 32,70^{\prime \prime} \mathrm{N}\right.$, $\left.73^{\circ} 03^{\prime} 45,75^{\prime \prime} \mathrm{W}\right)$ during October and November 2018.

Morphology. Body length of Colombian female specimens $=1064-1148 \mu \mathrm{m}(n=7$, average length $=1122$ $\mu \mathrm{m}$ ) (Fig. 2A). Body slender, with robust anteriorly rounded prosome; fifth pedigerous somite lightly pilose. Antennules 17-segmented (Fig. 2B), two distal segments with serrate hyaline membrane (Fig. 2C), distal half of hyaline membrane on last segment with three strong denticles forming deep notch (Figs. 1B, 2C); length ratio of segments $16 / 17=1.03$. Antenna composed of basipodite and 3-segmented endopodite (Fig. 3D). Frontal surface of basipodite with several spinule rows (Fig. 1C). Antennary Enp 2 with 7 setae (arrowheads in Fig. 3D), 4 of them long, inserted distolaterally; remaining 3 setae short, slender on medial position (Fig. 3D). Antennary Enp3 with 7 setae, 4 of them thicker than remaining 3 (Fig. 1M). Antennary exopod represented by single strong pinnate seta (arrow, Fig. 3D); exopod insertion point in the frontal surface of coxobasis with spinules.

Mandible gnathobase with three strong and four slender teeth plus dorsal seta with pinnate inner margin (Fig. 1A); as usual in genus, mandibular palp with 2 long and single short setae.

Urosome 5-segmented, ventral genital double somite smooth, expanded proximally (Fig. 3E), seminal receptacle weakly convex (arrow, Fig. 3C) with narrow lateral arms. Posterior margin of anal somite with continuous row of spinules dorsoventrally (Fig.1I); caudal rami 2.8 times as long as wide, inner margin hirsute (Fig. 1I). Lateralmost terminal caudal seta 3 times as long as lateral 
caudal seta, lateral median terminal caudal seta 1.4 times as long as medialmost terminal caudal seta, medial median terminal caudal seta 1.2 times as long as urosome, dorsal caudal seta as long as lateralmost terminal caudal seta.

Maxilla (Fig. 1D) and maxilliped (Fig. 1E) structure and armature typical of genus (Suárez-Morales \& Gutiérrez-Aguirre 2001).

P1-P4 EXP and ENP 3-segmented. Inner basipodal margin of P1 with short, strong spine barely reaching beyond distal margin of first endopodal segment (Figs. $1 \mathrm{~F}, 2 \mathrm{D}, 3 \mathrm{~A}$ ), frontal surface of basipodite ornamented with long spinules (Fig. 1F), intercoxal sclerite of P1-P2 caudally smooth; caudal surface of P3, P4 sparsely pilose (Fig 1H, 1L). Intercoxal sclerite of $\mathrm{P} 4$ with pair of large, acute projections (Figs. 1H, 2E, 3B). P4ENP3 2.25 times as long as wide, terminal spines subequal (Fig. 1G, 3B). Pediger 5 laterally pilose, P5 typical of genus, with relatively long proximal seta (Figs. 1J, 2F). P6 with two short spiniform elements plus one long seta (Fig. 1K).

\section{Discussion}

The morphology of the seven adult female specimens from La Guajira, Colombia agrees with previous descriptions and illustrations of the species (Dussart \& Frutos 1986, Gutiérrez-Aguirre et al. 2006, SuárezMorales et al. 2020).

Mesocyclops paranaensis can be separated from its closest congeners by a unique combination of characters including: 1) leg 4 intercoxal sclerite with two large, acute projections, 2) P3, P4 intercoxal sclerite caudally slightly pilose 3 ) seminal receptacle with narrow lateral arms and anterior margin weakly convex, 4) antennary endopodite- 2 with seven setae and insertion of antennary exopodal seta with spinules, 5) frontal surfaces of P1 basipodite ornamented with long spinules, 6) posterior margin of female anal somite with continuous row of spinules, and 7) inner margin of caudal ramus hirsute. These distinctive traits are present in our Colombian specimens.

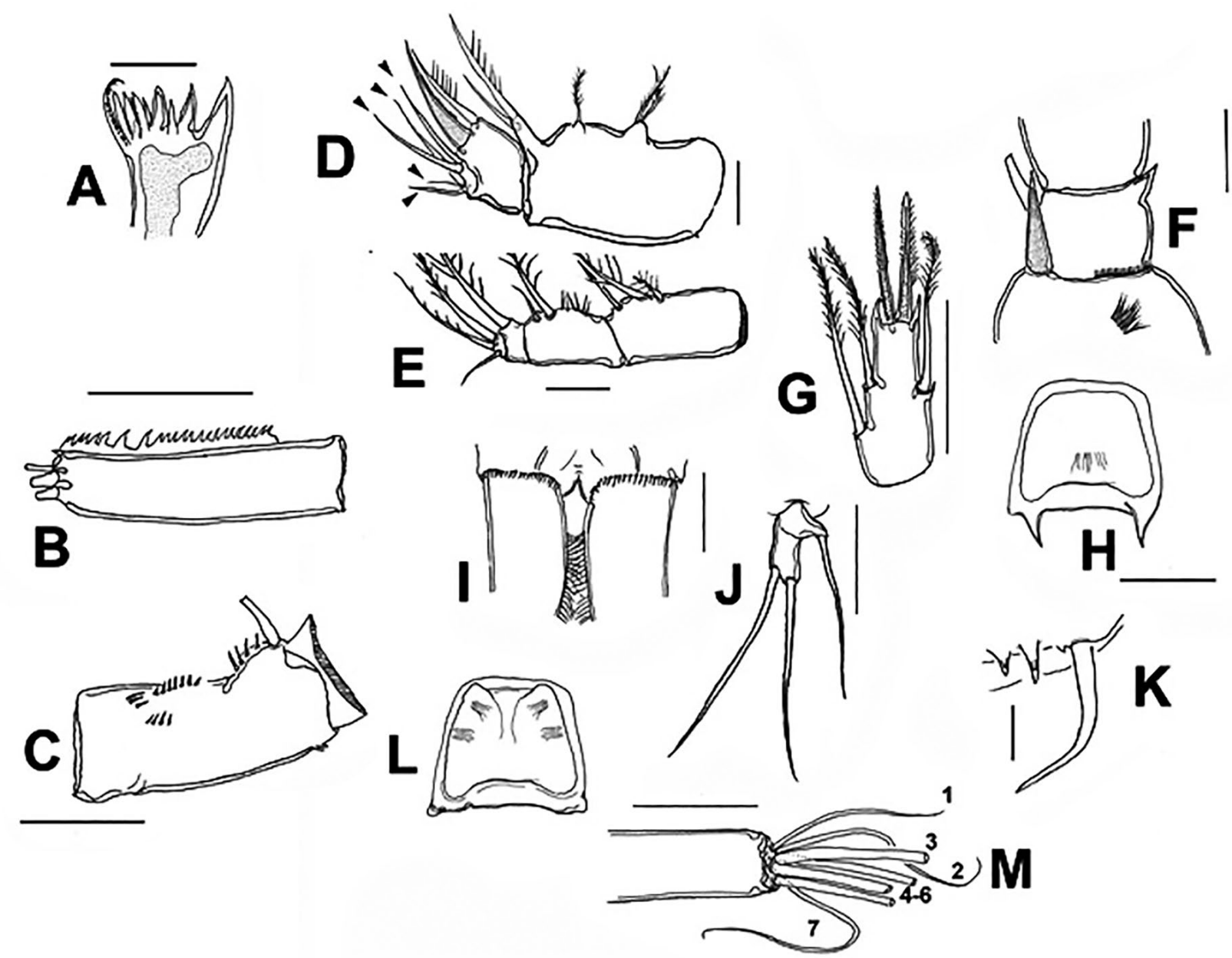

Figure 1. Mesocyclops paranaensis Dussart \& Frutos, 1986, adult female from ephemeral pond, northern Colombia. A. mandible blade. B. antennule, last segment showing serrate hyaline membrane. C. antennary basipodite, frontal view. D. maxilla with endopodal setae arrowed. E. maxilliped. F. P1 inner basipodal spiniform seta. G. P4 ENP3. H. P4 intercoxal sclerite, caudal view. I. caudal rami and posterior margin of anal somite, dorsal view. J. P5. K. P6. L. P3 intercoxal sclerite. M. distal setae of third antennary endopodal segment. Scale bars: $A, J=25 \mu \mathrm{m}, \mathrm{B}, \mathrm{C}, \mathrm{G}, \mathrm{H}, \mathrm{M}=50 \mu \mathrm{m}, \mathrm{F}=25 \mu \mathrm{m}$. 

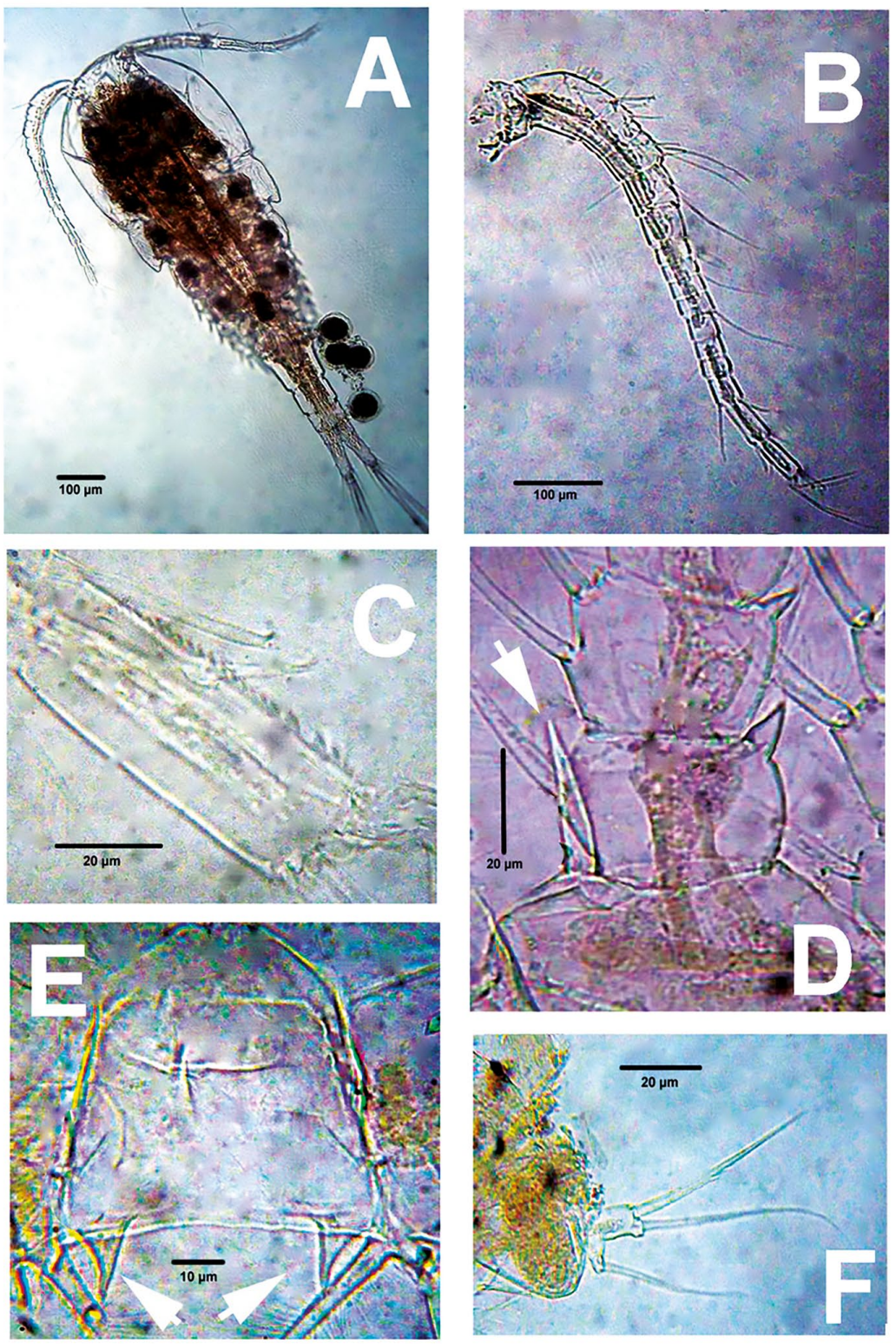

Figure 2. Mesocyclops paranaensis Dussart \& Frutos, 1986, adult female from ephemeral pond, northern Colombia. A. Habitus, dorsal view. B. antennule. C. same, last segment showing hyaline membrane. D. P1 inner basipodal spine (arrowed). E. P4 intercoxal sclerite, caudal view, showing acute processes (arrowed). F. P5.

A few subtle differences were observed in our Colombian specimens: 1) the inner distal spine of P4ENP3 is slightly longer than the outer spine (Fig. 1G) vs. equally long spines in the Argentinian population (Dussart \& Frutos 1986, fig. 46); 2) with a size range of $1064-1148 \mu \mathrm{m}$, our female specimens are noticeably smaller than those examined by Dussart and Frutos (1986) $(1700 \mu \mathrm{m})$ and Hołyńska et al (2003) $(1200-1700 \mu \mathrm{m})$ from Argentina and by Lowndes (1934) $(1244-1550 \mu \mathrm{m})$ from Paraguay; 3 ) the P4ENP3 is 2.25 times as long as wide in our Colombian specimens (Figs. 1G, 3B) vs. $2.2-2.5$ in the Argentinian populations (Dussart \& Frutos 1986, fig. 46; Hołyńska et al. 2003, fig. 30A). Also, the lateral arms of the seminal receptacle are straight in the Argentinian population (Dussart \& Frutos 1986, Fig. 49) and slightly curved in the Colombian specimens (Fig. 3C). In addition, this species appears to be uncommon within its distribution range and only a few specimens have been taxonomically examined (Hołyńska et al. 2003); until sufficient comparative information is available, it is premature to suggest that the Colombian population could represent a distinct species. Instead, it is suggested that sampling efforts should be increased in the species distributional range to examine its intraspecific variability in more detail and thus define its taxonomic status within the genus.

The genus Mesocyclops was divided by Hołyńska (2006) into seven clades. Mesocyclops paranaensis was included in the annulatus-clade which contains at least three other Neotropical species (i.e., M. intermedius Pesce, 1985; M. ellipticus Kiefer, 1936; M. annulatus (Wierzejski, 1892)), and one Afrotropical (M. tenuisaccus (G.O. Sars, 1927)). 

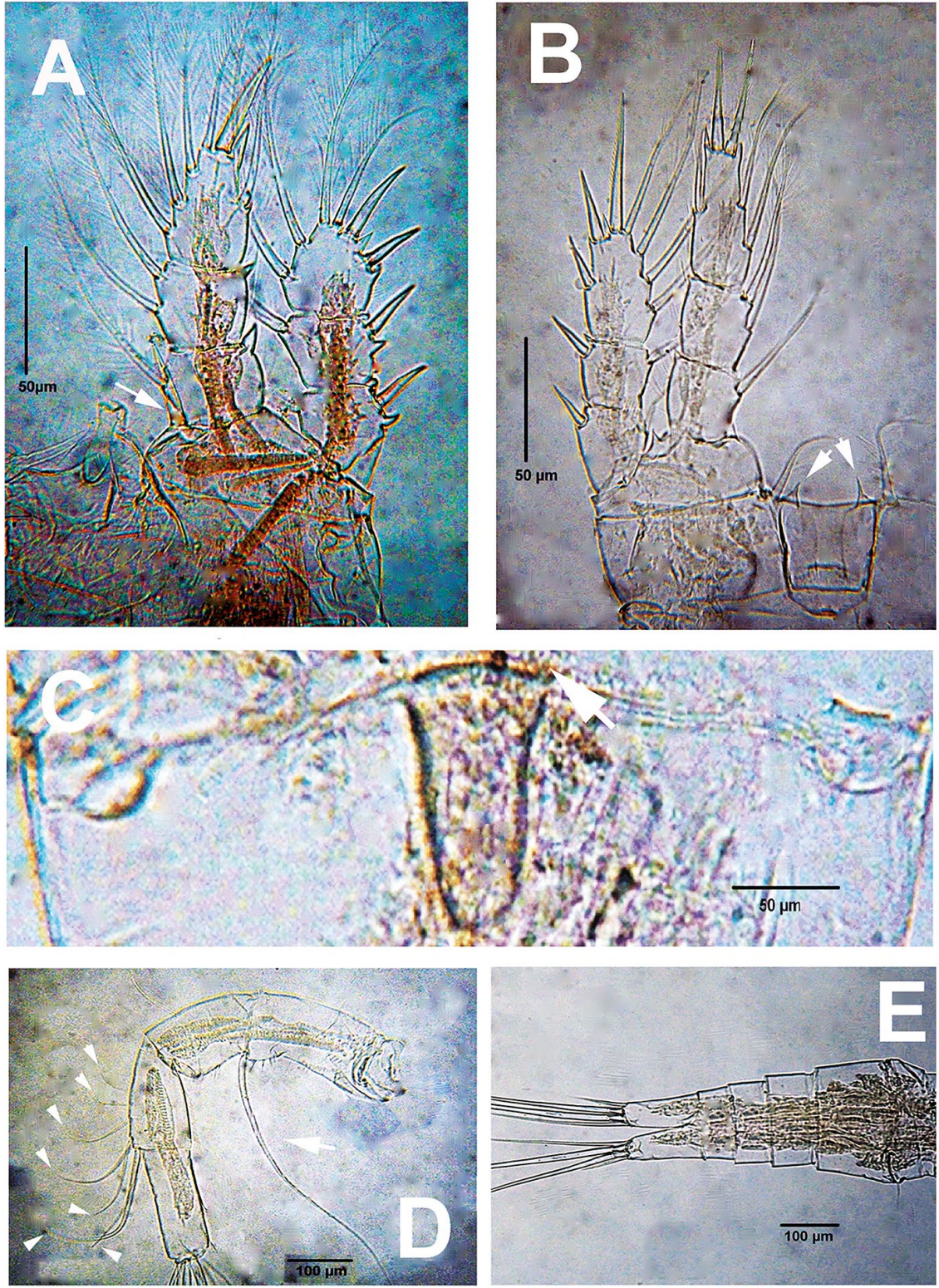

Figure 3. Mesocyclops paranaensis Dussart \& Frutos, 1986, adult female from ephemeral pond, northern Colombia. A. P1, anterior view showing inner basipodal spine (arrowed). B. P4 anterior view showing intercoxal sclerite with acute processes (arrowed). C. genital field, ventral view showing weakly convex anterior margin of seminal receptacle (arrow). D. antenna showing exopodal seta (arrow) and Exp2 setae (arrowheads). E. urosome, ventral view.

In the Neotropical region, M. paranaensis can be confused with $M$. intermedius and $M$. annulatus but they can be distinguished by the following characters: 1) the ornamentation of the posterior margin of the anal somite of M. paranaensis and M annulatus consists of a dorsoventrally continuous spinule row (Gutiérrez-Aguirre et al. 2006, fig. 8F, present data, Fig. 2I, Hołyńska et al. 2003, fig. 26H) whereas a discontinuous pattern is present in M. intermedius (Gutiérrez-Aguirre et al., 2006, fig. $8 \mathrm{E}$ );2) the inner margin of caudal rami is hirsute in both M. paranaensis and M. annulatus (Gutiérrez-Aguirre et al. 2006, fig. 8F, present data, Fig. 1I; Holyńska et al. 2003, figs. 26G) vs. a few scattered hair-like elements found in M. intermedius (Gutiérrez-Aguirre et al. 2006, fig. 8E; Suárez-Morales et al. 2020, fig. 21.25 U); 3) the antennary Enp2 of both M. paranaensis and M. intermedius are armed with 7 setae (Hołyńska et al. 2003; present data, Fig. 3D) vs. 9 such setae in M. annulatus (Hołyńska et al. 2003); 4) inner spine on P4EXP3 almost as long as the outer spine in M. paranaensis (Dussart \& Frutos 1986, fig. 46; Holyńska et al. 2003, fig 30H; present data, fig. 3B) and M. intermedius (Pesce 1985, fig. 64) whereas in M. annulatus they are unequal in length (Hołyńska et al. 2003, figs. 27J); 5); frontal surface of P1 basipodite ornamented with long spinules in M. paranaensis (Hołyńska et al. 2003, fig. 30G; present data, Fig. 1F) and M. intermedius (Hołyńska et al. 2003, fig. 32G) whereas in $M$. annulatus the long spinules are absent (Hołyńska et al. 2003, fig. 27A); 6) length ratio of seta on proximal segment/distal seta on second segment on P5 less than 1 in M. paranaensis (Dussart \& Frutos 1986, fig. 47; present data, Figs. 1J, 2F,) and M. annulatus (Hołyńska et al. 2003, 
fig. 26C) whereas in $M$. intermedius greater than 1 (Pesce 1985, fig. 60); 7) length/width ratio of caudal ramus is smaller in M. paranaensis (about 2.8 - 4.2, Hołyńska et al. 2003, fig. 30A; present data, fig. 3E), and M. intermedius (3.0, Pesce 1985, fig. 60; Hołyńska et al. 2003, fig. 32C) than in M. annulatus ( 5.0 - 5.5, Hołyńska et al. 2003, figs. $26 \mathrm{H})$; and 8) $M$. intermedius is a smaller $(520-610 \mu \mathrm{m})$ species (Pesce 1985) than M. paranaensis (1064 - 1770 $\mu \mathrm{m}$, Dussart \& Frutos 1986; Lowndes 1934; Hołyńska et al. 2003; present data) and M. annulatus (1300 - 2000 $\mu \mathrm{m}$ Hołyńska et al. 2003).

In the surveyed area, M. paranaensis was found associated to the aquatic vegetation (water temperature = $31.4{ }^{\circ} \mathrm{C}$, conductivity $255 \mu \mathrm{S} / \mathrm{cm}, \mathrm{pH} 7.68$ ). The presence of $M$. paranaensis in adjacent areas seems very likely, so a wider distribution in South America might be expected. The diversity and distribution of this genus in the Neotropical region deserve further research.

\section{Literature cited}

Alekseev VR, Haffner DG, Vaillant JJ, Yusoff FM. 2013. Cyclopoid and calanoid copepod biodiversity in Indonesia. Journal of Limnology. 72(s2):e12-e12. doi:10.4081/jlimnol.2013.s2.e12.

Dussart BH, Frutos SM. 1986(1985). Sur quelques copépodes d'Argentine. Revue d'hydrobiologie tropicale 18 (4): 305-314

Fuentes-Reinés JM, Zoppi De Roa E. Torres R. 2013. Calanoida and Cyclopoida (Copepoda: Crustacea) from Ciénaga Grande de Santa Marta, Colombia. Métodos en Ecología y Sistemática 82(2):54-103.

Gutiérrez-Aguirre MA, Suárez-Morales E, Cervantes-Martínez A, Elías-Gutiérrez M, Previattelli D. 2006. The neotropical species of Mesocyclops (Copepoda, Cyclopoida): an upgraded identification key and comments on selected taxa. Journal of Natural History. 40(9-10):549570. https://doi.org/10.1080/00222930600761837

Hołyńska M, Reid JW, Ueda H. 2003. Genus Mesocyclops Sars, 1914. In: Ueda H, Reid JW. (Eds.). Copepoda: Cyclopoida genera Mesocyclops and Thermocyclops. Guides to the Identification of the Microinvertebrates of the Continental Waters of the World 20. Leiden: Backhuys Publishers, 12-213.

Hołyńska M. 2006. Phylogeny of Mesocyclops (Copepoda: Cyclopidae) inferred from morphological characters. Zoological Journal of the Linnean Society. 147(1):1-70. https://doi.org/10.1111/j.1096-3642.2006.00231.x.

Huys R. \& G.A. Boxshall. 1991. Copepod Evolution. London: The Ray Society. 468 pp.

Lowndes AG. 1934. Reports of an Expedition to Brazil and Paraguay in 1926-7 supported by the Trustees of the Percy Sladen Memorial Fund and the Executive Committee of the Carnegie Trust for Scotland. Copepoda. Journal of the Linnean Society of London, Zoology. 39(263):83131. https://doi.org/10.1111/j.1096-3642.1934. tb00260.x.

Luong TD, Thanh DN, Hai HT. 2020. The freshwater copepod genus Mesocyclops (Copepoda, Cyclopoida, Cyclopidae) in Vietnam. Academia Journal of Biology. 42(4). doi:10.15625/2615-9023/v42n4.15310. https:// www.vjs.ac.vn/index.php/vjbio/article/view/15310.
Papa RDS, Hołyńska MK. 2013. An overview of the limnetic Cyclopidae (Crustacea, Copepoda) of the Philippines, with emphasis on Mesocyclops. Journal of Limnology. 72(s2):e14-e14. https://doi.org/10.4081/jlimnol.2013.s2.e14.

Pesce GL. 1985. Cyclopids (Crustacea, Copepoda) from West Indian Groundwater Habitats. Bijdragen tot de Dierkunde. 55(2):295-323. https://doi. org/10.1163/26660644-05502009.

Suarez-Morales E, McLelland J, Reid J. 1999. The Planktonic Copepods of Coastal Saline Ponds of the Cayman Islands with Special Reference to the Occurrence of Mesocyclops ogunnus Onabamiro, an Apparently Introduced Afro-Asian Cyclopoid. Gulf and Caribbean Research. 11(1):51-55. https://doi.org/10.18785/ grr.1101.07.

Suárez-Morales, E. \& M. Gutiérrez-Aguirre. 2001. Morfología y taxonomía de los Mesocyclops (Crustacea: Copepoda: Cyclopoida) de México. CONACYT- ECOSUR. México. $202 \mathrm{pp}$.

Suárez-Morales E, Gutiérrez-Aguirre MA, Gómez S, Perbiche-Neves G, Previattelli D, dos Santos-Silva EN, da Rocha CEF, Mercado-Salas NF, Marques TM, Cruz-Quintana Y, et al. 2020. Chapter 21 - Class Copepoda. In: Rogers DC, Damborenea C, Thorp J, editors. Thorp and Covich's Freshwater Invertebrates (Fourth Edition). Academic Press. p. 663-796. https://doi. org/10.1016/B978-0-12-804225-0.00021-6

Tran DL, Hołyńska M. 2015. A New Mesocyclops with Archaic Morphology from a Karstic Cave in Central Vietnam, and Its Implications for the Basal Relationships within the Genus. Annales Zoologici 65(4):661-686. doi:10.3 161/00034541ANZ2015.65.4.010.

\section{Agradecimientos / Acknowledgments:}

We are deeply indebted to Jorge David Olivero Villanueva for help in the field. This study was financially supported by the Grupo de Investigación en Biodiversidad y Ecología (GIBEA).

\section{Conflicto de intereses / Competing interests:}

The authors declare that they have no conflict of interest.

\section{Rol de los autores / Authors Roles:}

JFR, PEE: collected the samples and obtained the digital photos of the specimens. ESM: made the drawings. JFR, ES-M: identified the specimens and wrote the text.

\section{Fuentes de financiamiento / Funding:}

The Grupo de investigación en Biodiversidad y Ecología received total support through the Universidad del Magdalena, Vicerrectoría de investigación, Fonciencia 2017.

\section{Aspectos éticos / legales; Ethics / legals:}

Authors declare that in the research they have not incurred in unethical practices nor illegal omissions. The zooplankton sampling (copepods) was performed under research permission NO 01144 granted by Autoridad Nacional de Licencias Ambientales (ANLA), Colombia. 